\title{
ЗНАЧЕНИЕ КРИМИНАЛИСТИЧЕСКОГО АСПЕКТА УСТАНОВЛЕНИЯ МЕХАНИЗМА СОВЕРШЕНИЯ ПРЕСТУПЛЕНИЯ В ВОПРОСАХ КВАЛИФИКАЦИИ ДЕЙСТВИЙ ПРЕСТУПНИКА
}

\section{THE IMPORTANCE OF THE FORENSIC ASPECT OF ESTABLISHING \\ A MECHANISM FOR COMMITTING \\ A CRIME IN MATTERS OF QUALIFYING THE ACTIONS OF THE CRIMINAL}

\section{Proshin}

Summary. The author believes that the basis for the correct qualification of any crime is the need for a criminalistic establishment of a model of the mechanism for committing the corresponding crime. The author confirms this point of view on the example of the analysis of such crimes as tax evasion payable by the organization (Article 199 of the Criminal Code of the Russian Federation) and tax fraud (Article 159 of the (C RF). An analysis of the mechanisms for committing these crimes allows one to correctly qualify the actions of individuals within the framework of the legislation on taxes and fees related to providing the taxpayer with the right to set off or refund excessively paid taxes and fees, and to recover the amount of value added tax and excise taxes.

Keywords: tax legal relations, taxpayer, tax crime, tax fraud, mechanism for committing a crime, tax evasion, seizing budget funds, tax benefit, tax refund from the budget, tax credit. $\mathbf{y}$ становление механизма совершения любого преступления является основополагающим фактором, лежащим в основе его раскрытия.

Помимо самого факта раскрытия преступления, наиболее объективно полно восстановленная модель механизма совершённого преступления позволяет правильно квалифицировать действия (бездействия) субъекта преступления.

Если взять за основу научного анализа и практического применения определение понятия механизма совершения преступления, данное А.М. Кустовым [1], то, на наш взгляд, при полном восстановлении модели механизма любого совершённого преступления ошибка в квалификации действий преступника будет сведена к минимуму. По мнению А. М. Кустова, основные элементы механизма преступления создают основу системы взаимодействия между участниками преступного события и окружающей средой. С точки зрения А.М. Кустова

\author{
Прошин Владимир Михайлович \\ Д.ю.н., доцент, Московский государственный \\ областной университет \\ Advokat.proshin.v.m@gmail.com
}

Аннотация. Автор полагает, что в основе правильной квалификации любого преступления лежит необходимость криминалистического установления модели механизма совершения соответствующего преступления. Данную точку зрения автор подтверждает на примере анализа таких составов преступлений, как уклонение от уплаты налогов, подлежащих уплате организацией (ст. 199 УК РФ) и налоговое мошенничество (ст. 159 УК РФ). Анализ механизмов совершения данных преступлений позволяет правильно квалифицировать действия лиц в рамках законодательство о налогах и сборах, связанных с предоставлением налогоплательщику права зачёта или возврата излишне уплаченных налогов и сборов, возмещения сумм налога на добавленную стоимость и акцизов.

Ключевые слова: налоговые правоотношения, налогоплательщик, налоговое преступление, налоговое мошенничество, механизм совершения преступления, уклонение от уплаты налогов, завладение бюджетными средствами, налоговая выгода, возмещение налога из бюджета, зачёт налога.

[2], механизм преступления - это система процессов взаимодействия участников преступления, как прямых, так и косвенных, между собой и с материальной средой, сопряженных с использованием соответствующих орудий, средств и иных отдельных элементов обстановки.

Зависимость между объективно восстановленной моделью совершённого преступления и правильной квалификацией действий преступника можно проиллюстрировать на примере таких составов преступлений, как уклонение от уплаты налогов, подлежащих уплате организацией (ст. 199 УК РФ) и налоговое мошенничество (ст. 159 УК РФ), взяв в качестве конструктивных частей модели механизма данных составов предложенные А. М. Кустовым элементы [3].

Вопрос квалификации данных деяний заключается в следующем. Законодательство о налогах и сборах предоставляет налогоплательщику право зачёта или возврата излишне уплаченных налогов и сборов (ст. 78 
НК РФ), возмещения сумм налога на добавленную стоимость (ст. 176 НК РФ) и акцизов (ст. 203 НК РФ) [4]. При использовании налогоплательщиком фиктивных документов для подтверждения наличия у него указанных прав, как средство обмана налогового органа, и возникает необходимость разграничения двух вышеуказанных составов. Судебная практика и публикуемые мнения в юридической литературе склоняются к тому правилу квалификации, что, если на основании заведомо ложных документов субъект получил возмещение налога из бюджета в форме возврата налога, действия квалифицируются как мошенничество, а если в форме зачёта налога - как уклонение от уплаты налогов. Нам представляется такой подход неправильным к разрешению данного вопроса в силу следующего.

Преступное уклонение от уплаты налогов характеризуется тем, что субъект преступления, находясь в системе налоговых правоотношений и будучи обременённый обязанностью заплатить к соответствующей дате установленный налог, направляет свои интеллектуально-волевые усилия на невыполнение этой обязанности либо на выполнение её ненадлежащим образом, дающие ему возможность получить незаконную налоговую выгоду в форме возврата налога из бюджета или в форме налогового зачёта. В данном случае, на наш взгляд, действия субъекта преступления являются действиями по уклонению от уплаты налогов без относительно к форме получения налоговой выгоды, ибо преступные действия лица, как налогоплательщика, протекают в рамках его налоговых правоотношений с бюджетной системой государства. Изготовление и предоставление фиктивных документов осуществляется именно лицом, имеющим статус налогоплательщика (его представителя), и уже, к моменту их изготовления, обременённым обязанностью уплатить законно установленный налог в результате наличия в своём владении объекта налогообложения, как определённого обстоятельства, имеющего стоимостную, количественную или физическую характеристику, с наличием которого законодательство о налогах и сборах связывает возникновение у налогоплательщика обязанности по уплате налога (ст. 38 НК РФ). То есть в данном случае импульсным мотивационным толчком к формированию механизма совершения налогового преступления является наличие обязанности по уплате налога, и будучи обременённым этой обязанностью налогоплательщик (его представитель) приступает к формированию механизма совершения налогового преступления, реализация которого приводит к нарушению баланса публичных и частных интересов в системе налоговых правоотношений посредством получения налогоплательщиком незаконной налоговой выгоды.

Формирование механизма совершения налогового мошенничества (ст. 159 УК РФ), особенно момент нача- ла его формирования, значительно отличается от налогового преступления. При формировании умысла на совершение налогового мошенничества субъект преступления не находится в рамках налоговых правоотношений и к этому моменту не владеет объектом налогообложения, как определённым обстоятельством, имеющим стоимостную, количественную или физическую характеристику, с наличием которого законодательство о налогах и сборах связывает возникновение у налогоплательщика обязанности по уплате налога (ст. 38 НК РФ) [5], а значит не обременён обязанностью по уплате соответствующего налога, и, следовательно, не является налогоплательщиком. Формирование механизма совершения налогового мошенничества, как раз и предусматривает этап вхождения в налоговые правоотношения как необходимый элемент события обмана для получения формального основания по изготовлению и предоставлению документов, формирующих фиктивное правовое основание получения налоговой выгоды в форме возврата налога из бюджета или в форме налогового зачёта. То есть, вступление в налоговые правоотношения, наделение себя статусом налогоплательщика во взаимоотношениях с налоговым органом, изготовление и представление фиктивных документов, -все эти действия являются элементами единого механизма обмана, подчинённого корыстной цели завладения бюджетными средствами в виде налоговой выгоды.

Таким образом, действия лица, являющегося участником налоговых правоотношений и обременённого как налогоплательщик обязанностью уплатить к определённой дате установленный налог, по незаконному получению налоговой выгоды хоть и напоминают в отдельных фрагментах их отправления мошенничество, связанное с незаконным завладением бюджетными средствами путём обмана, но в масштабе объёмного анализа совершённого механизма преступления являются в части упомянутой их схожести средством и способом уклонения от уплаты налогов. Квалификация действий как налоговое мошенничество возможна только когда субъект данного преступления, будучи не обременённым налоговой обязанностью, систему налоговых правоотношений и статус налогоплательщика рассматривает и использует как средство формирования обманного механизма незаконного завладения бюджетными средствами. Целью совершения преступления, связанного с уклонением от уплаты налогов, является именно уклонение от уплаты налогов со стороны налогоплательщика (его представителя) в режиме реализации его отношения к реально существующим налоговым обязанностям. Целью совершения налогового мошенничества является незаконная материальная выгода за счёт бюджетной системы государства, где налоговые правоотношения являются одним из элементов формы обмана в формируемом субъектом преступления общем механизме мошенничества. 
ЛИТЕРАТУРА

1. Кустов А. М. Механизм преступления в криминалистической теории и практики: Учебное пособие. М., 1997; Кустов А. М. Механизм преступления и противодействие расследованию: Учебное пособие. Ставрополь, 1997; Кустов А. М. Механизм преступления: понятия и элементы: Брошюра. М., 1996.

2. Веренич И.В., Кустов А. М., Прошин В. М. Криминалистическая теория механизма преступления: Монография. Под науч. Ред. Кустова А. М. М., 2014. C. 137-152.

3. Статьи 199 и 159 Уголовного кодекса Российской Федерации.

4. Статьи 78, 176 и 203 Налогового кодекса Российской Федерации.

5. Статья 38 Налогового кодекса Российской Федерации.

( Прошин Владимир Михайлович ( Advokat.proshin.v.m@gmail.com ).

Журнал «Современная наука: актуальные проблемы теории и практики»

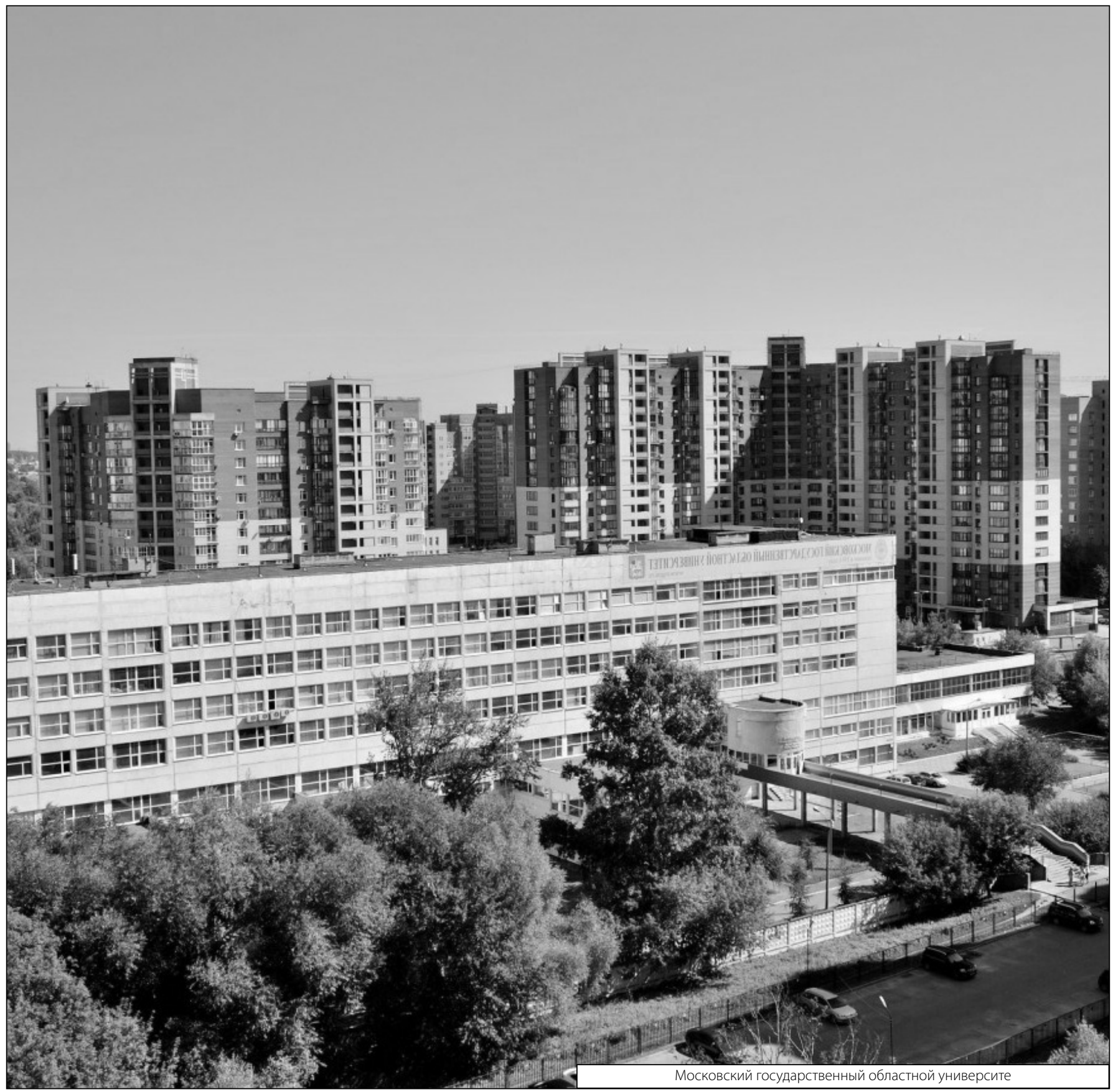

